\title{
Potential Risk Levels of Invasive Fire Blight in Apple Orchards Around the World
}

\author{
R. D. A. Vieira ${ }^{1}$, L. Zambolim ${ }^{2}$, R. S. Ramos ${ }^{3}$, R. S. da Silva ${ }^{4}$, J. Ebel ${ }^{1} \&$ P. T. D. de Borba ${ }^{1}$ \\ ${ }^{1}$ Companhia Integrada de Desenvolvimento Agrícola de Santa Catarina (CIDASC), Lages, SC, Brazil \\ ${ }^{2}$ Universidade Federal de Viçosa, Bioagro, Viçosa, MG, Brazil \\ ${ }^{3}$ Departamento de Entomologia, Universidade Federal de Viçosa, Bioagro, Viçosa, MG, Brazil \\ ${ }^{4}$ Departamento de Agronomia, Universidade Federal dos Vales de Jequitinhonha e Mucuri, Diamantina, MG, \\ Brazil \\ Correspondence: L. Zambolim, Universidade Federal de Viçosa, Bioagro, Viçosa, MG, 36.570-440, Brazil. Tel: \\ 55-319-9547-0203. E-mail: laerciozambolim@gmail.com
}

Received: July 27, $2020 \quad$ Accepted: September 27, $2020 \quad$ Online Published: October 15, 2020

doi:10.5539/jas.v12n11p17 URL: https://doi.org/10.5539/jas.v12n11p17

The research is financed by $C N P Q, C A P E S$ and $C I D A S C$.

\begin{abstract}
Fire blight, a disease of apple trees caused by Erwinia amylovora, occurs worldwide except in South America, South-Central Africa, and most of Oceania. Ecological niche models can determine the potential distribution of species and measure the risk of pest invasion. This study aims to develop global climate suitability models using MaxEnt software for E. amylovora and to determine the regions in which apple cultivation and the bacterium are most likely to co-occur. Most occurrence data for E. amylovora $(93 \%)$ are from the northern hemisphere, distributed between 63.90 to 14.56 degree days in regions of Africa, Central America, North America, Asia, and Europe. The only country in the southern hemisphere that this bacteria has been detected is New Zealand (Oceania). Apples are cultivated on every continent except Antarctica, between 61.55 to 44.41 degree days. We find that regions of South-Eastern Africa, Argentina, Australia, Southern Brazil, Bolivia, Chile, China, the United States, Madagascar, Morocco, Mexico, New Zealand, Peru, Tunisia, Uruguay, and the majority of Europe are suitable for both E. amylovora and apple cultivation. These results provide information on the potential worldwide distribution of E. amylovora in apple production area.
\end{abstract}

Keywords: invasive species, Erwinia amylovora, modelling, MaxEnt

\section{Introduction}

Erwinia amylovora (Burrill, 1882) Winslow et al. (1920) causes fire blight, a pathogen that affects the apple tree Malus domestica Borkh. It is the most severe pathogen affecting this crop, threatening the production in areas where it is present (EPPO, 2004). This species belongs to the family Enterobacteriaceae and is classified as a gram-negative and facultative anaerobic bacterium (Raymundo \& Ries, 1980). Epiphytism occurs without parasitizing the host, and its survival depends on weather conditions (Thomson, 2000). Fire blight causes damage when it encounters a susceptible host, and when the weather conditions are favourable for disease development (Palacio Bielsa \& Cambra Alvarez, 2009). First described in the New York State, United States, in 1780 , the disease later spread to the east and west coasts of this country and regions of Canada (Palacio Bielsa \& Cambra Alvarez, 2009). It is now present in almost all continents, with recorded observations in North and Central America, Africa, Europe, Asia, and Oceania, though with no records in South America (European and Mediterranean Plant Protection Organization - EPPO) (2019). In the United States, the pathogen causes damages over USD 100 million per year (Norelli et al., 2003). Approximately 200 ha of orchards were eradicated in Morocco between 2006 and 2010, resulting in losses of around EUR 55 million (Fatmi, 2011).

Predictive modelling of species distribution using computer programs can provide relevant data on species invasion (Jarnevich et al., 2015; Kriticos et al., 2015). The models are useful tools for risk analysis, which is an essential instrument for assessing potential impacts on the spread of pest species, such as E. amylovora (Vilela \& 
Callegaro, 2013). MaxEnt is a model that predicts the distribution of probabilities that a species will be present in a particular locality, based on the principle of maximum entropy (Phillips et al., 2006). This software requires data on locations in which the pest and its host are known to occur (Kumar et al., 2015; Phillips \& Dudík, 2008; Merow et al., 2013).

Despite the severe impact that E. amylovora would have if it were introduced into new countries, at present, no studies have analyzed the invasion risk of this species. This study, therefore, aims to use MaxEnt modelling to predict suitable areas for E. amylovora and open-field cultivation of apples.

\section{Methodology}

\subsection{Distribution}

We used species occurrence data from the Centre for Agriculture and Biosciences International-CABI (2019), Global Biodiversity Information Facility-GBIF (2019), EPPO (2019), United States Department of Agriculture (USDA, 2019), and Food and Agriculture Organization of the Nations (FAO), 2016). Erwinia amylovora and M. domestica were recorded in 254 and 295 localities, respectively (Supplementary material). We then performed spatial filtering using the spThin package in the R software (Ripley, 2001). Data handling maintains the most significant number of occurrence records and checks all possible filter combinations, eliminating outliers and using a minimum distance of $10 \mathrm{~km}$ (Boria et al., 2014; Team, 2014), ensuring that each cell has only a single occurrence record.

\subsection{Climatic Data}

Our analysis considers nineteen bioclimatic variables (Tables S1 and S2) from the WorldClim version 1.4 dataset (Hijmans et al., 2017) and a spatial resolution of $2.5 \min$ (about $5 \mathrm{~km}$ ). This resolution is considered high-quality for analyses at the global scale (Elith \& Leathwick, 2009). WorldClim uses global climate records from 1960 to 1990 to estimate air temperature and rainfall (mean, maximum, and minimum), as well as other parameters such as seasonal variables and extreme climate indices (Hijmans \& Elith, 2013).

We used the SDMtools package in ArcGIS to remove highly correlated variables with a Pearson correlation coefficient of $r \geq 0.75$ as a cutoff, following Kumar et al. (2014). We kept one strongly correlated pair of variables in the dataset.

\subsection{Determination of Risk Levels}

The maximum test sensitivity plus specificity (MTSPS) was chosen to determine the distribution of suitability classes of E. amylovora in apple crops that are at risk of pest invasion. We used a cutoff for both species, with values above the cutoff considered unsuitable. The cutoff for E. amylovora and M. domestica was set at 0.3575 and 0.3457 , respectively.

\subsection{Validation}

The global distributions of E. amylovora and apple crops were obtained from the maximum entropy-based model using MaxEnt v. 3.3.3k (Phillips et al., 2006). The suitability index generated by MaxEnt ranges from 0 for not suitable to 1 for suitable. A total of 50,000 points were randomly selected for each species, representing areas of current occurrence. Sampling bias was generated in data collected without sampling from external sources. This procedure was made using a kernel density estimate in SDMToolbox (Brown, 2014; Jarnevich et al., 2015). The polarization surface compensates for sampling intensity and possible sampling bias (Jarnevich et al., 2015).

The settings used in the MaxEnt models for E. amylovora and M. domestica were based on specific resource-type combinations and the regularization multiplier (RM) (Jarnevich et al., 2015; Merow et al., 2013). Combined sets of linear $(\mathrm{L})$, quadratic $(\mathrm{Q})$, product $(\mathrm{P})$, threshold $(\mathrm{T})$, and hinge $(\mathrm{H})$ features were used to control the number of parameters, and thus the model complexity for both species.

The MaxEnt fade-by-clamping option was used to eliminate extrapolations outside the environmental range (Owens et al., 2013). The contribution of environmental variables was estimated using the jackknife method. Of the response curves generated by MaxEnt, only those representing relationships between the probabilities of presence for each species and each environmental predictor were chosen. All response curves were evaluated based on biological logic, and those that failed this test were eliminated.

The omission rate (OR) and the area under the curve (AUCcv) were used to evaluate the models (Kumar et al., 2015; Liu et al., 2013). The OR measures the extent to which the model omits the existence of localities, where the target species occurs. The AUCcv is obtained from the integration of the receiver operating characteristic (ROC) curve, which is the relationship of sensitivity with the complement of specificity (1-specificity). Sensitivity is defined as the proportion of real presence concerning the total occurrences predicted by the model, 
while specificity is the proportion of real absences in the total absences predicted by the model (Manel et al., 2001). Thus, the validation test verifies if the model detects the presence of the target species in the areas under the ROC curve. The results can be interpreted as the probability of existing presence and absence data being correctly predicted by the model.

We performed a 10x cross-validation on the MaxEnt data. AUCcv was also used to determine the presence of background data. An AUCcv value of 0.5 indicates that the forecasts are not different from random, while values below 0.5 are worse than random, 0.5-0.7 represent poor performance, 0.7-0.9 represent satisfactory to moderate performance, and values above 0.9 indicate high performance (Peterson \& Soberón, 2012). For the OR, the value at $10 \%$ is 0.10 , and the sensitivity test value at $0 \%$ is 0 . Poor performance is indicated when the OR value exceeds the predicted rate (Boria et al., 2014).

\section{Results}

The data on the global distribution of E. amylovora and M. domestica are shown in Figure 1. After spatial filtering to reduce the autocorrelation in the occurrence records, our dataset was comprised of a total of 254 and 293 occurrence points of E. amylovora and M. domestica, respectively.

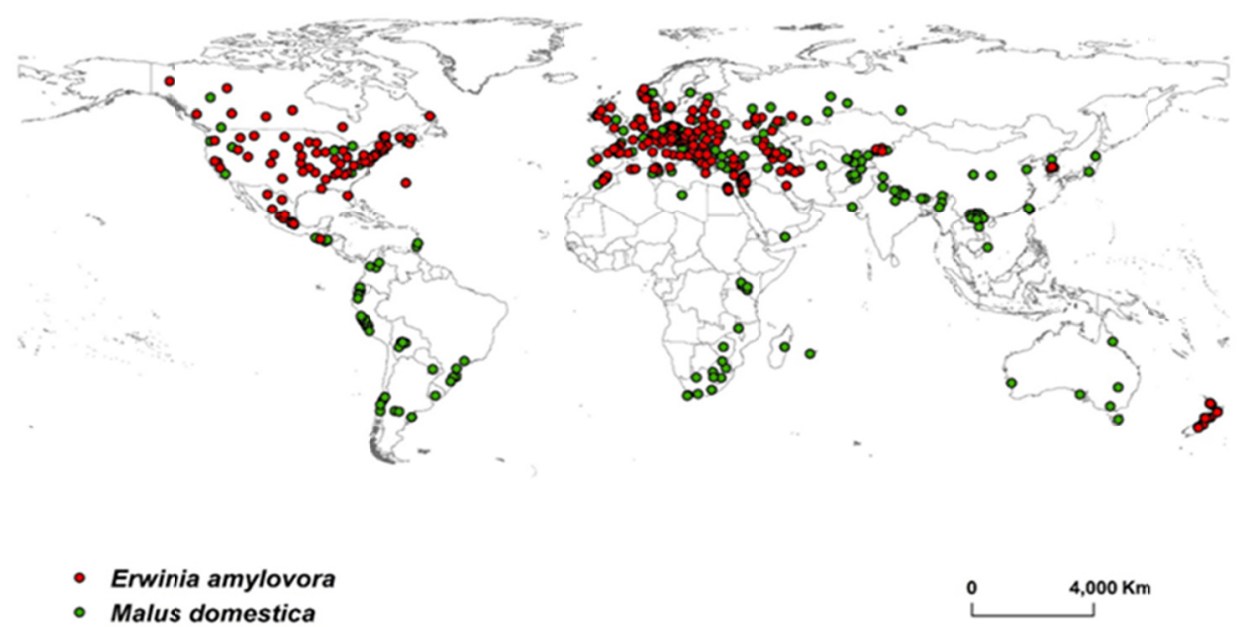

Figure 1. Known global occurrences of Erwinia amylovora and Malus domestica

The current known distribution of E. amylovora is in temperate regions of the northern hemisphere, in North and Central America, Europe, Asia, Africa, and some areas of Oceania. Meanwhile, M. domestica is widely distributed in the temperate regions of both the northern and southern hemispheres, in North, Central and South America, Europe, Asia, Africa, and Oceania. For the species modelling process, the criterion for variable selection is an important step, as it optimizes the performance of the models and the importance of the results obtained. Six bioclimatic variables that were not correlated with each other were used in the model studied. These variables are all related to temperature or precipitation, which are important climatic elements in the distribution of bacteria and plant development. They can influence to a greater or lesser extent the growth and development of the species studied (Table S3).

Table 1 shows the analysis of the environmental variables considered in the E. amylovora suitability model. The annual mean temperature was the most important variable associated with suitability (bio $1 ;{ }^{\circ} \mathrm{C} ; 80.9 \%$ contribution). It was followed by annual precipitation (bio12; $\mathrm{mm} ; 8.4 \%$ contribution), precipitation of the driest month (bio14; $\mathrm{mm} ; 5.4 \%$ contribution), precipitation seasonality (bio15; unitless; $2.0 \%$ contribution), annual temperature range (bio $7 ;{ }^{\circ} \mathrm{C} ; 1.9 \%$ contribution), and mean diurnal range (bio2; ${ }^{\circ} \mathrm{C} ; 1.4 \%$ contribution) (Table 1). 
Table 1. Environmental variables considered in the niche model for the bacterium Erwinia amylovora and their mean percentage contribution to the model, calculated based on ten repeated runs. Statistics were calculated using all occurrences $(n=254)$

\begin{tabular}{|c|c|c|c|}
\hline \multirow{2}{*}{ Description (variables) } & \multirow{2}{*}{$\begin{array}{l}\text { Mean value of the variable } \\
\text { (minimum-maximum) }\end{array}$} & \multicolumn{2}{|c|}{ Characteristics of the selected model } \\
\hline & & Contribution & Importance of permutation \\
\hline Annual mean temperature $\left(\right.$ bio $\left.1 ;{ }^{\circ} \mathrm{C}\right)$ & $11.6(-5.6-25.2)$ & 80.9 & 80.9 \\
\hline Annual rainfall (bio $12 ; \mathrm{mm})$ & $777.0(24.0-2301.0)$ & 8.4 & 9.5 \\
\hline Precipitation of the driest month (bio14; mm) & $34.9(0.0-112.0)$ & 5.4 & 3.0 \\
\hline Precipitation seasonality (CV) (bio15) & $39.6(7.0-115.0)$ & 2.0 & 1.1 \\
\hline Annual temperature range (bio $7{ }^{\circ} \mathrm{C}$ ) & $30.5(14.0-54.2)$ & 1.9 & 2.2 \\
\hline Mean diurnal range $\left(\mathrm{bio} 2 ;{ }^{\circ} \mathrm{C}\right)$ & $10.5(4.5-18.1)$ & 1.4 & 3.3 \\
\hline Isothermality (bio3) & $35.2(20.0-72.0)$ & - & - \\
\hline Temperature seasonality $(\mathrm{SD} \times 100)($ bio4$)$ & $7060.2(905.0-15167.0)$ & - & - \\
\hline Maximum temperature of the warmest month $\left(\right.$ bio $5 ;{ }^{\circ} \mathrm{C}$ ) & $27.4(14.7-46.0)$ & - & - \\
\hline Minimum temperature of the coldest month (bio6; ${ }^{\circ} \mathrm{C}$ ) & $-3.1(-32.3-14.4)$ & - & - \\
\hline Mean temperature of the wettest quarter (bio8; ${ }^{\circ} \mathrm{C}$ ) & $13.6(-3.7-27.2)$ & - & - \\
\hline Mean temperature of the driest quarter $\left(\right.$ bio $\left.9 ;{ }^{\circ} \mathrm{C}\right)$ & $9.8(-18.6-35.7)$ & - & - \\
\hline Mean temperature of the warmest quarter $\left(\right.$ bio $\left.10 ;{ }^{\circ} \mathrm{C}\right)$ & $20.4(10.1-35.7)$ & - & - \\
\hline Mean temperature of the coldest quarter (bio $11 ;{ }^{\circ} \mathrm{C}$ ) & $2.3(-24.2-17.3)$ & - & - \\
\hline Precipitation of the wettest month (bio13; mm) & $104.6(6.0-358.0)$ & - & - \\
\hline Precipitation of the wettest quarter (bio $16 ; \mathrm{mm}$ ) & $281.5(0-849.0)$ & - & - \\
\hline Precipitation of the driest quarter (bio $17 ; \mathrm{mm}$ ) & $117.8(0-363.0)$ & - & - \\
\hline Precipitation of the warmest quarter (bio18; mm) & $194.9(0-763.0)$ & - & - \\
\hline Precipitation of the coldest quarter (bio19; mm) & $118(0-1865)$ & - & - \\
\hline
\end{tabular}

Note. Variables that were not selected for the model.

Concerning $M$. domestica, the mean annual temperature was the most important variable ( $71.6 \%$ contribution) (Table 2). It was followed by the mean diurnal range ( $10.3 \%$ contribution), annual temperature range $(9.3 \%$ contribution), annual precipitation ( $7.1 \%$ contribution), precipitation of the driest month ( $1.0 \%$ contribution), and precipitation seasonality $(0.7 \%$ contribution) (Table 2$)$. 
Table 2. Environmental variables considered in the niche model for apple crops and their mean percentage contribution to the model, calculated based on ten repeated runs. Statistics were calculated using all occurrences $(\mathrm{n}=293)$

\begin{tabular}{|c|c|c|c|}
\hline \multirow{2}{*}{ Description (variable) } & \multirow{2}{*}{$\begin{array}{l}\text { Mean value of the variable } \\
\text { (minimum-maximum) }\end{array}$} & \multicolumn{2}{|c|}{ Characteristics of the selected model } \\
\hline & & Contribution & Importance of permutation \\
\hline Annual mean temperature $\left(\right.$ bio $\left.1 ;{ }^{\circ} \mathrm{C}\right)$ & $13.0(-1.8-27.0)$ & 71.6 & 73.9 \\
\hline Mean diurnal range $\left(\mathrm{bio} 2 ;{ }^{\circ} \mathrm{C}\right)$ & $10.7(5.6-17.1)$ & 10.3 & 8.4 \\
\hline Annual temperature variation $\left(\right.$ bio $\left.7 ;{ }^{\circ} \mathrm{C}\right)$ & $28.1(9.5-49.5)$ & 9.3 & 10.4 \\
\hline Annual rainfall (bio12; mm) & $822.3(7.0-3313.0)$ & 7.1 & 5.6 \\
\hline Precipitation of the driest month (bio14; mm) & $25.3(0-123.0)$ & 1.0 & 1.0 \\
\hline Precipitation seasonality (CV) (bio15) & $52.1(8.0-153.0)$ & 0.7 & 0.6 \\
\hline Isothermality (bio3) & $41.0(19.0-92.0)$ & - & - \\
\hline Temperature seasonality $(\mathrm{SD} \times 100)($ bio4$)$ & $6085.8(198.0-13362.0)$ & - & - \\
\hline Maximum temperature of the warmest month $\left(\right.$ bio $5 ;{ }^{\circ} \mathrm{C}$ ) & $27.5(11.1-42.4)$ & - & - \\
\hline Minimum temperature of the coldest month (bio6; ${ }^{\circ} \mathrm{C}$ ) & $-0.6(-27.2-21.9)$ & - & - \\
\hline Mean temperature of the wettest quarter (bio8; ${ }^{\circ} \mathrm{C}$ ) & $14.9(-6.5-30.4)$ & - & - \\
\hline Mean temperature of the driest quarter $\left(\right.$ bio $\left.9 ;{ }^{\circ} \mathrm{C}\right)$ & $11.5(-14.3-28.9)$ & - & - \\
\hline Mean temperature of the warmest quarter $\left(\right.$ bio $\left.10 ;{ }^{\circ} \mathrm{C}\right)$ & $20.5(4.7-32.6)$ & - & - \\
\hline Mean temperature of the coldest quarter (bio $11 ;{ }^{\circ} \mathrm{C}$ ) & $5.0(-19.8-26.0)$ & - & - \\
\hline Precipitation of the wettest month (bio $13 ; \mathrm{mm}$ ) & $134.9(1.0-721.0)$ & - & - \\
\hline Precipitation of the wettest quarter (bio $16 ; \mathrm{mm}$ ) & $359.0(3.0-1935.0)$ & - & - \\
\hline Precipitation of the driest quarter (bio $17 ; \mathrm{mm}$ ) & $89.6(0-392.0)$ & - & - \\
\hline Precipitation of the warmest quarter (bio $18 ; \mathrm{mm}$ ) & $260.7(0-1935.0)$ & - & - \\
\hline Precipitation of the coldest quarter (bio $19 ; \mathrm{mm}$ ) & $159.6(0-923.0)$ & - & - \\
\hline
\end{tabular}

Note. Variables that were not selected for the model.

Of a total of 12 models that use different combinations, the linear, quadratic and hinge (LQH) model showed the best performance for E. amylovora, considering six environmental variables (bio1, bio2, bio7, bio12, bio14, and bio15). The LQH model resulted in an RM value of 1.5 , AUCcv of over 0.9 , and the lowest OR values (10\% of 0.1098 and $0 \%$ of 0.004 ) (Table 3 ). 
Table 3. Index of the statistical performance of the model generated by MaxEnt for Erwinia amylovora

\begin{tabular}{lllllll}
\hline \multirow{2}{*}{ No. } & \multicolumn{3}{c}{ Model features } & & Area below the curve & \multicolumn{2}{c}{ Omission rate } \\
\cline { 2 - 3 } & Selected variables ${ }^{\dagger}$ & Type & RM & & & $10 \%$ \\
\hline $1^{*}$ & bio1, bio2, bio7, bio12, bio14, bio15 & LQH & 1.5 & $0.9077 \pm 0.0225$ & 0.004 & 0.1098 \\
2 & bio1, bio2, bio7, bio12, bio14, bio15 & LH & 1.5 & $0.9039 \pm 0.0233$ & 0.008 & 0.11 \\
3 & bio1, bio2, bio7, bio12, bio14, bio15 & LQPH & 2 & $0.9088 \pm 0.0209$ & 0.004 & 0.121 \\
4 & bio1, bio2, bio7, bio12, bio14, bio15 & LH & 1 & $0.9065 \pm 0.0229$ & 0.004 & 0.126 \\
5 & bio1, bio2, bio7, bio12, bio14, bio15 & LQPH & 1 & $0.9093 \pm 0.0232$ & 0.012 & 0.126 \\
6 & bio1, bio2, bio7, bio12, bio14, bio15 & LQH & 2 & $0.9044 \pm 0.0226$ & 0.004 & 0.126 \\
7 & bio1, bio2, bio7, bio12, bio14, bio15 & LQH & 1 & $0.9082 \pm 0.0214$ & 0.004 & 0.134 \\
8 & bio1, bio2, bio7, bio12, bio14, bio15 & LQPH & 1.5 & $0.9093 \pm 0.0227$ & 0.004 & 0.142 \\
9 & bio1, bio2, bio7, bio12, bio14, bio15 & LQPTH & 1 & $0.9119 \pm 0.0215$ & 0.016 & 0.142 \\
10 & bio1, bio2, bio7, bio12, bio14, bio15 & LQPT & 1.5 & $0.9102 \pm 0.0222$ & 0.004 & 0.15 \\
11 & bio1, bio2, bio7, bio12, bio14, bio15 & LQPT & 2 & $0.9092 \pm 0.0224$ & 0.0042 & 0.151 \\
12 & bio1, bio2, bio7, bio12, bio14, bio15 & LQPTH & 1.5 & $0.9084 \pm 0.0221$ & 0.004 & 0.154
\end{tabular}

Note. * Selected model; ${ }^{\dagger}$ The names of the variables are described in Table $1 ;{ }^{\S} \mathrm{L}=$ linear component, $\mathrm{Q}=$ quadratic component, $\mathrm{P}=$ product, $\mathrm{T}=$ threshold, and $\mathrm{H}=$ hinge; ${ }^{\infty} \mathrm{RM}=$ regularization multiplier.

Out of the various combinations of the 12 models analyzed, the linear and hinge (LH) model had the best performance for $M$. domestica, with six environmental variables (bio1, bio2, bio7, bio12, bio14, and bio15). The LH model resulted in an RM value of 1.0, AUCcv of over 0.9 , and the lowest OR values $(10 \%$ of 0.1199 , and $0 \%$ of 0.0048 ) (Table 4 ).

Table 4. Index of the statistical performance of the model generated by MaxEnt for apple crops

\begin{tabular}{cllllll}
\hline \multirow{2}{*}{ No. } & \multicolumn{2}{c}{ Model features } & & Area below the curve & \multicolumn{2}{c}{ Omission rate } \\
\cline { 3 - 4 } & Selected variables ${ }^{\dagger}$ & Type & RM & ( standard error $)$ & $0 \%$ & $10 \%$ \\
\hline $1^{*}$ & bio1, bio2, bio7, bio12, bio14, bio15 & LH & 1 & $0.9001 \pm 0.026$ & 0.0048 & 0.1199 \\
2 & bio1, bio2, bio7, bio12, bio14, bio15 & LQH & 1 & $0.9001 \pm 0.0242$ & 0.0095 & 0.1208 \\
3 & bio1, bio2, bio7, bio12, bio14, bio15 & LQPH & 1 & $0.9004 \pm 0.0254$ & 0.0046 & 0.1247 \\
4 & bio1,bio2, bio7, bio12, bio14, bio15 & LQP & 1 & $0.8871 \pm 0.0238$ & 0.0091 & 0.1247 \\
5 & bio1, bio2, bio7, bio12, bio14, bio15 & LQPTH & 1.5 & $0.8959 \pm 0.0273$ & 0.0093 & 0.1249 \\
6 & bio1, bio2, bio7, bio12, bio14, bio15 & LQPT & 2 & $0.8938 \pm 0.0256$ & 0.0091 & 0.1251 \\
7 & bio1, bio2, bio7, bio12, bio14, bio15 & LQH & 2 & $0.8951 \pm 0.0246$ & 0.0093 & 0.1251 \\
8 & bio1, bio2, bio7, bio12, bio14, bio15 & LQPT & 1.5 & $0.8948 \pm 0.0266$ & 0.0093 & 0.1288 \\
9 & bio1, bio2, bio7, bio12, bio14, bio15 & LQP & 1.5 & $0.8855 \pm 0.0242$ & 0.0046 & 0.129 \\
10 & bio1, bio2, bio7, bio12, bio14, bio15 & LQPTH & 2 & $0.8943 \pm 0.0257$ & 0.0139 & 0.1292 \\
11 & bio1, bio2, bio7, bio12, bio14, bio15 & LQPH & 2 & $0.8961 \pm 0.0254$ & 0.0137 & 0.1295 \\
12 & bio1, bio2, bio7, bio12, bio14, bio15 & LQPH & 1.5 & $0.8983 \pm 0.0254$ & 0.0046 & 0.1299
\end{tabular}

Note. * Selected model; ${ }^{\dagger}$ The names of the variables are described in Table $1 ;{ }^{\S} \mathrm{L}=$ linear component, $\mathrm{Q}=$ quadratic component, $\mathrm{P}=$ product, $\mathrm{T}=$ threshold, and $\mathrm{H}=$ hinge; ${ }^{\infty} \mathrm{RM}=$ regularization multiplier. 
The MaxEnt model indicated suitability for E. amylovora in several regions of the world, mainly in the southeastern United States, southern South America, Africa, Oceania, Europe, and southeastern Asia (Figure 2A).

The model indicated suitability for $M$. domestica in regions of Brazil, Uruguay, Argentina, Chile, Bolivia, and Peru in South America, and Mexico, the United States, and Canada in North America (Figure 2B). The entire European continent, except for Norway, presented suitability for crops, besides Tunisia, Algeria, Morocco, and some regions of southeastern Africa. In Asia, the suitability was detected mainly in areas of Japan, South Korea, and North Korea, besides some border regions of southeastern Asia. In Oceania, New Zealand and some areas of Australia also showed suitability for $M$. domestica. The model also indicated suitability in some areas of Madagascar and northeastern Brazil, in which M. domestica is not yet cultivated (Figure 2B).

The model detected areas that are suitable for both species in all continents except Antarctica. In the Americas, appropriate areas were found in southern Brazil, Uruguay, mainly southeastern Argentina, southern Chile, south-central Bolivia, southwestern Peru, central Ecuador, some regions of Colombia, western Mexico, northeastern United States, and some points in extreme southern Canada (Figure 2C).

Almost the entire Europe showed suitability for the two species studied, including Albania, Austria, Belarus, Belgium, Bosnia and Herzegovina, Bulgaria, Croatia, Cyprus, Czech Republic, Denmark, Estonia, Finland, France, Georgia, Germany, Greece, Netherlands, Hungary, Ireland, Italy, Kosovo, Latvia, Lithuania, Luxembourg, Macedonia, Malta, Moldova, Montenegro, Poland, Portugal, Romania, Russia, Serbia, Slovakia, Slovenia, Spain, Sweden, Switzerland, Ukraine, and the United Kingdom (England, Northern Ireland, Scotland, and Wales) (Figure 2C).

In the Asian continent, the suitability for both species was found in Japan, South Korea, southeastern China, and border regions with Bhutan, Nepal, India, and Pakistan. Some points were also detected in Indonesia, Afghanistan, Iran, Turkmenistan, Kazakhstan, Syria, Yemen, Kyrgyzstan, and Tajikistan (Figure 2C).

In Africa, suitability was higher in the southern region of the continent, including South Africa and some areas of Namibia, Angola, Zimbabwe, Tanzania, Kenya, Ethiopia, Madagascar, Tunisia, Algeria, and Morocco (Figure 2C).

In Oceania, New Zealand and the southern and southwestern regions of Australia were the most suitable regions for E. amylovora and M. domestica (Figure 2C). 


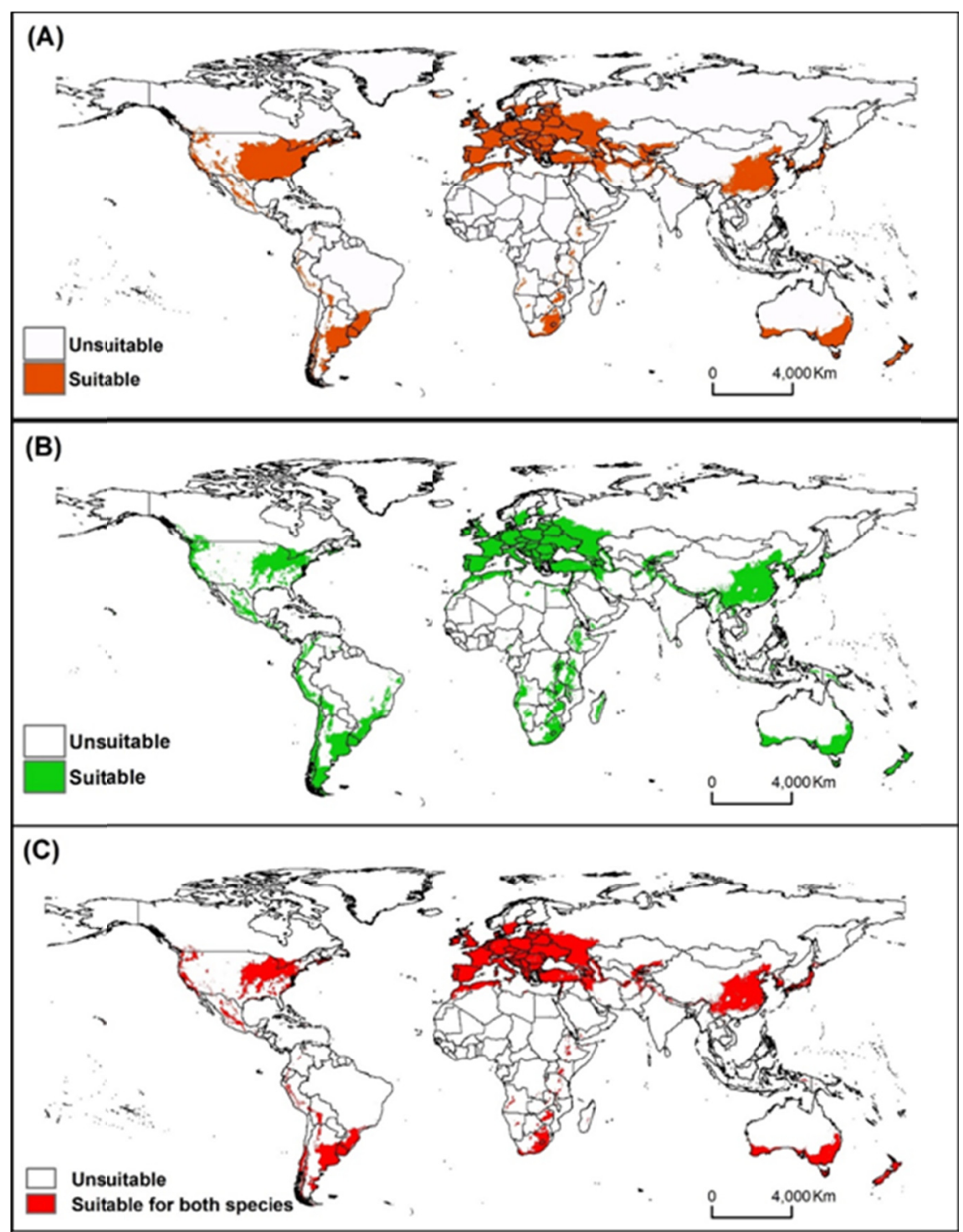

Figure 2. Suitability of the habitat under current climatic conditions using the MaxEnt model for (A) Erwinia amylovora, (B) Malus domestica, and (C) both species

The jackknife test confirmed that the variables that best contributed to the chosen model for E. amylovora were the mean annual temperature (bio1), annual precipitation (bio12), precipitation in the driest month (bio14), precipitation seasonality (bio 15), annual temperature range (bio7), and mean diurnal range (bio2) (Figure 3). 


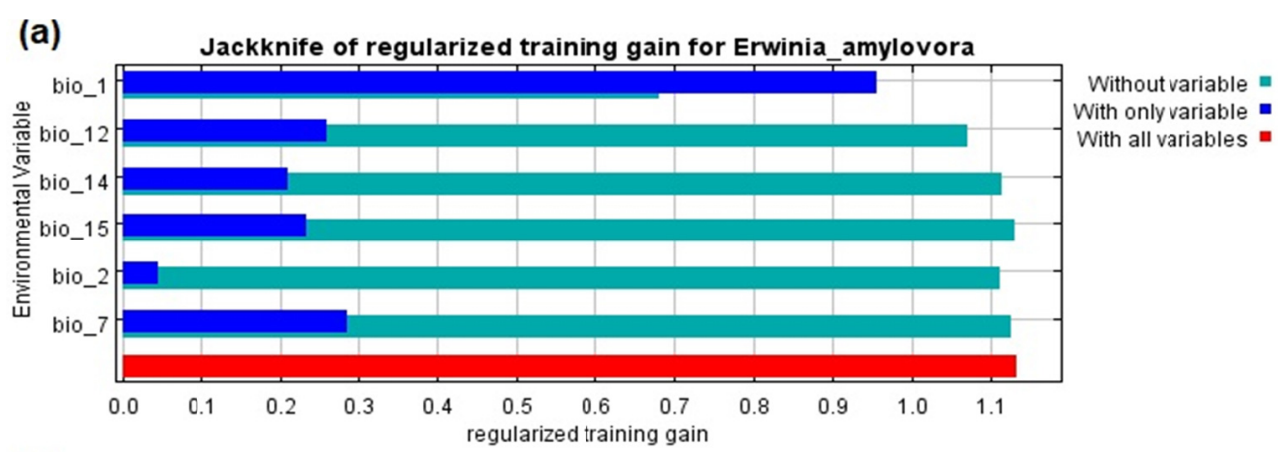

(b)

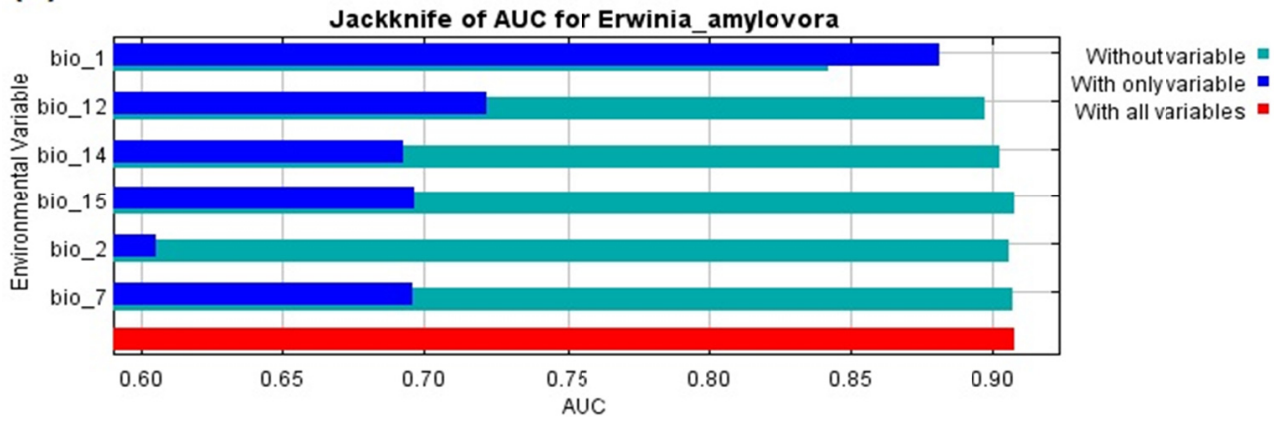

Figure 3. Relative importance of environmental variables based on the jackknife test: (a) regularized training gain and (b) AUCcv in the model for the Erwinia amylovora

For $M$. domestica, the variables that best contributed to the chosen model according to the jackknife test were the mean annual temperature (bio1), mean diurnal range (bio2), annual temperature range (bio7), annual precipitation (bio12), precipitation in the driest month (bio14), and precipitation seasonality (bio 15) (Figure 4).

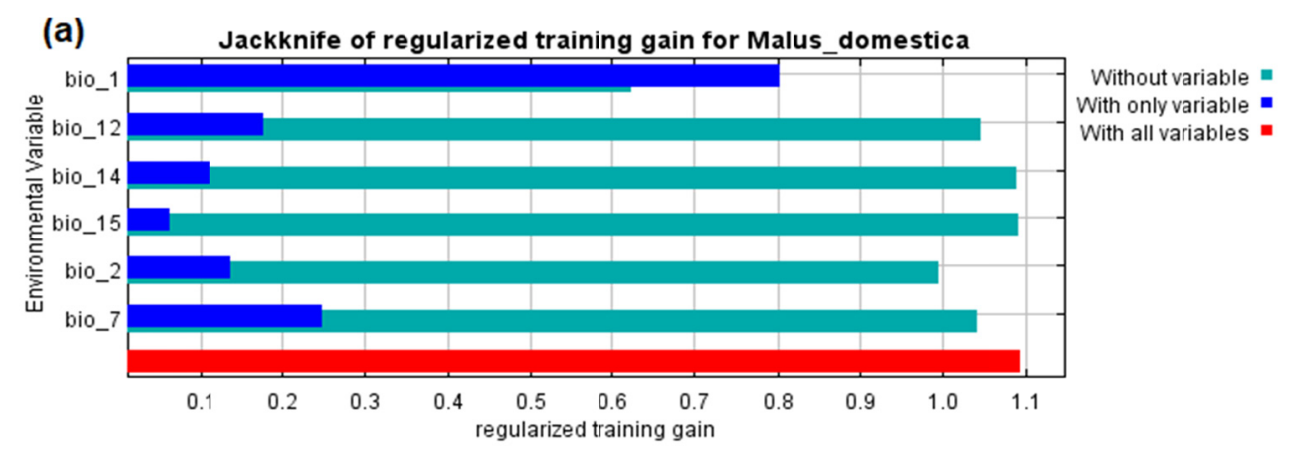

(b)

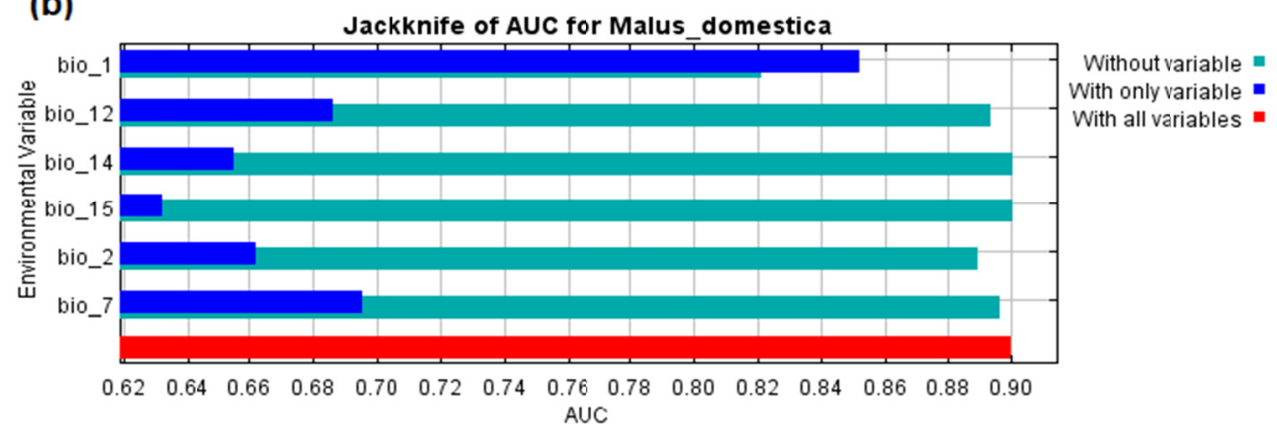

Figure 4. Relative importance of environmental variables based on the jackknife test: (a) regularized training gain and (b) AUCcv in the model for Malus domestica 
Erwinia amylovora was shown to be present in areas with mean annual temperatures between $5.6^{\circ} \mathrm{C}$ and $25.2^{\circ} \mathrm{C}$, mean annual temperature ranges between $14{ }^{\circ} \mathrm{C}$ and $54.2{ }^{\circ} \mathrm{C}$, precipitation in the driest month below $112 \mathrm{~mm}$, and precipitation seasonality with a coefficient of variation (CV) between 7.0 and 115 (Figure 5).
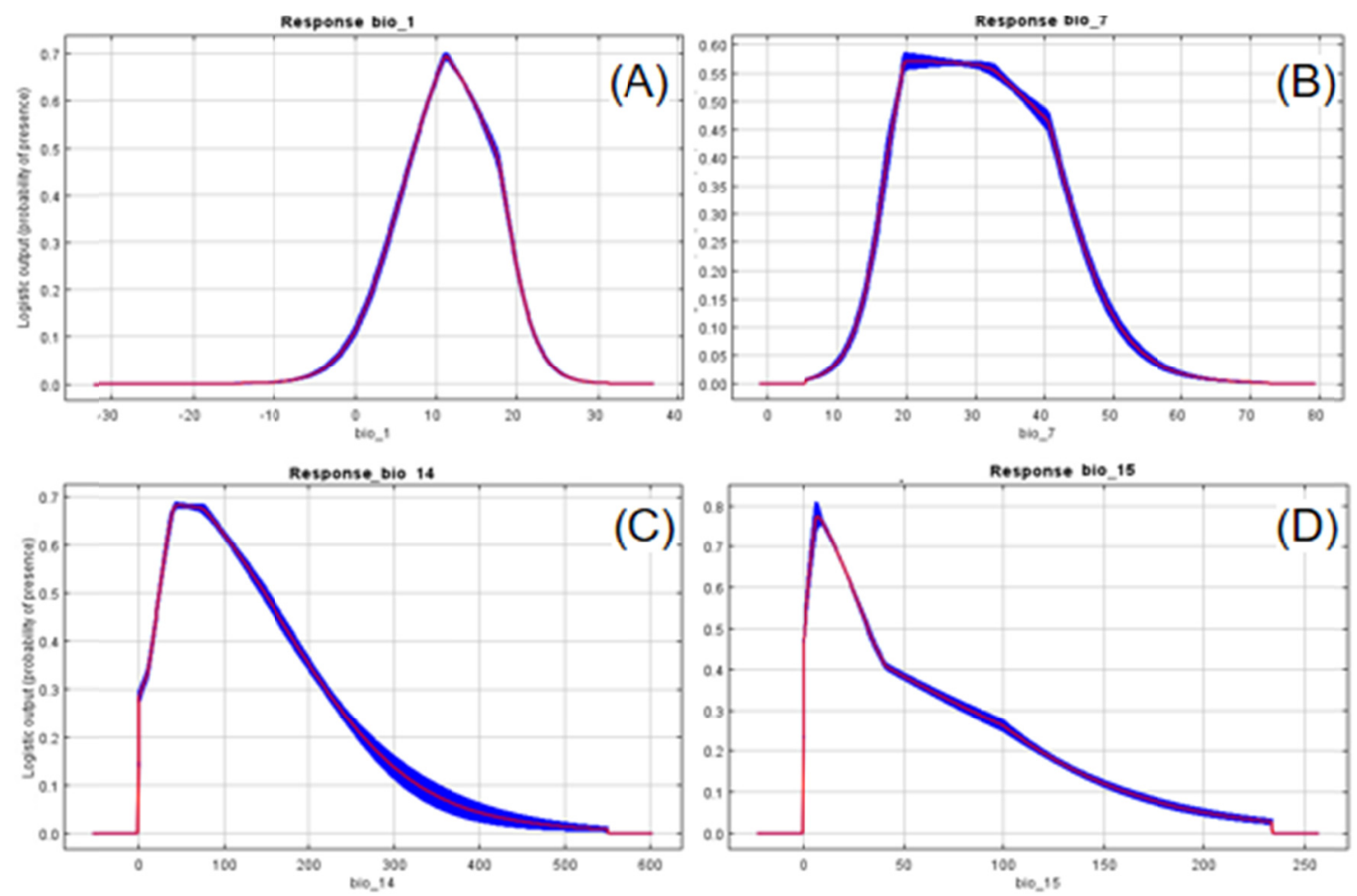

Figure 5. Response curves of the best predictors of the model for the bacterium Erwinia amylovora: (A) mean annual temperature (bio1; $\left.{ }^{\circ} \mathrm{C}\right),(\mathrm{B})$ annual temperature range $\left(\right.$ bio7; $\left.{ }^{\circ} \mathrm{C}\right),(\mathrm{C})$ precipitation of the driest month (bio $14 ; \mathrm{mm}$ ), and (D) precipitation seasonality (coefficient of variation) (bio $15 ; \mathrm{mm})$

No suitability was observed for E. amylovora at mean annual temperatures (bio1; ${ }^{\circ} \mathrm{C}$ ) below $-5.6{ }^{\circ} \mathrm{C}$ and above $25.2{ }^{\circ} \mathrm{C}$. There was also no suitability in areas with an annual temperature range (bio7; ${ }^{\circ} \mathrm{C}$ ) below $14{ }^{\circ} \mathrm{C}$ and above $54.2^{\circ} \mathrm{C}$. There was also a reduction in suitability in areas with precipitation during the driest month (bio14; $\mathrm{mm}$ ) higher than $112 \mathrm{~mm}$, and in areas with the precipitation seasonality (bio 15; mm) below 7.0mm and higher than $115 \mathrm{~mm}$ (Figure 5).

Meanwhile, $M$. domestica was shown to be present in areas with mean annual temperatures between $-1.8^{\circ} \mathrm{C}$ and $27.0{ }^{\circ} \mathrm{C}$, mean annual temperature ranges between $9.5^{\circ} \mathrm{C}$ and $49.5{ }^{\circ} \mathrm{C}$, precipitation in the driest month below $123 \mathrm{~mm}$, and precipitation seasonality between 8.0 and $153 \mathrm{~mm}$ (Figure 6). 

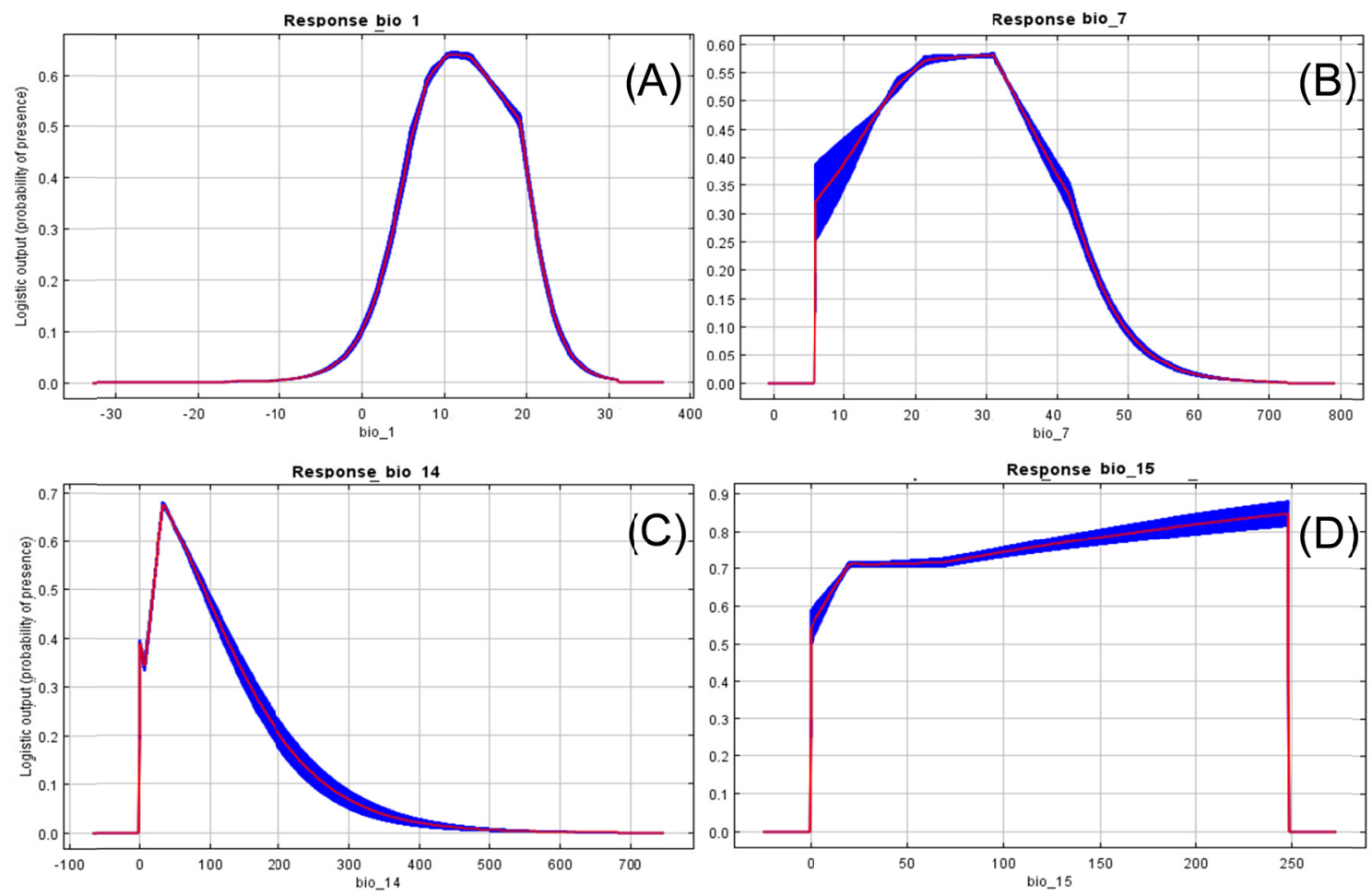

Figure 6. Response curves of the best predictors of the model for Malus domestica: (A) mean annual temperature (bio1; ${ }^{\circ} \mathrm{C}$ ), (B) annual temperature range (bio $7 ;{ }^{\circ} \mathrm{C}$ ), (C) precipitation of the driest month (bio14; mm), and (D) precipitation seasonality (coefficient of variation) (bio15; mm)

\section{Discussion}

The modelled global distributions showed a larger area for M. domestica than for E. amylovora. The bulk of the presence data on E. amylovora (93\%) is from the northern hemisphere, in regions of Africa, North and Central America, Asia, and Europe, and the only observations from the southern hemisphere were recorded in New Zealand. Observations of $M$. domestica, meanwhile, were reported for all continents except Antarctica. The climatic conditions for the occurrence of both species are very similar since the host species $M$. domestica is adapted to temperate and subtropical climates (Hoffmann \& Nachtigall, 2004).

Mean annual temperature (bio1) showed the most significant contribution to the suitability of both species in the AUC jackknife analyses. Previous studies on the distribution of other plant pathogens report that this variable likewise contributed the most to the pathogen's species distribution modelling (da Silva Galdino et al., 2016; Kumar et al., 2015).

The model generated by MaxEnt indicated the best suitability conditions for the presence of both species in regions of temperate and humid subtropical climates, with mean annual temperatures of $5.6-25.2{ }^{\circ} \mathrm{C}$ for $E$. amylovora and -1.8-27.0 ${ }^{\circ} \mathrm{C}$ for M. domestica. Johnson (2000) reported that the temperature of $27^{\circ} \mathrm{C}$ is optimum for the development of E. amylovora, though its development is impaired at temperatures above $36{ }^{\circ} \mathrm{C}$, with paralysis at $39{ }^{\circ} \mathrm{C}$ (Holt, 1994; Paulin, 2000). However, cell division can occur between $5{ }^{\circ} \mathrm{C}$ and $31{ }^{\circ} \mathrm{C}$, allowing the pathogen to disperse in a variety of conditions (Cambra et al., 2002). The ideal temperature range for the apple tree during the spring (vegetative period) is between $18{ }^{\circ} \mathrm{C}$ and $23{ }^{\circ} \mathrm{C}$, not exceeding $25{ }^{\circ} \mathrm{C}$ in the summer. However, regions suitable for the cultivation of $M$. domestica have lower temperatures in the winter periods, which are necessary for its breaking dormancy (temperatures below $7.2^{\circ} \mathrm{C}$ for a minimum of 600 hours). This is reflected in the lower mean annual temperatures when compared to the ideal temperature range of $E$. amylovora (Hoffmann \& Nachtigall, 2004).

Suitable areas for both E. amylovora and M. domestica were found in regions of southeastern Africa, Argentina, Australia, southern Brazil, Bolivia, Chile, China, the United States, most of Europe, Madagascar, Morocco, Mexico, New Zealand, Peru, Tunisia, and Uruguay. Erwinia amylovora is considered a quarantine organism by the European Union law and the EPPO, meaning that phytosanitary measures such as analysis of symptomatic and asymptomatic plants are required. Cambra et al. (2002) report that the introduction of infected propagating 
material from fruit trees and ornamental plants is an important dispersion factor of E. amylovora over long distances. Therefore, the source regions of this bacterium should be monitored since even asymptomatic plants can spread the bacteria if ideal conditions occur among the host, pathogen, and environment (Cambra et al., 2002).

According to Rodoni et al. (1998), E. amylovora was detected in Melbourne, Australia, in 1997, an area that our study indicates as suitable for the propagation of this pathogen. In the following years, the Australian authorities carried out quarantine actions, leading to the country to become the only one in the world to eradicate this species (Rondoni et al. 2001), in 1999. However, since our model indicated that the range of M. domestica in the country overlapped with the potential range of E. amylovora, defence actions are imperative in order to avoid a possible reentry of the disease.

In the United States, the distribution area of E. amylovora is larger than the cultivation areas of M. domestica. Since other host species (pears and quinces) are cultivated in the United States, measures to contain and suppress the pest are necessary to minimize its damage. For the cultivation of apples in these regions, the use of resistant varieties, healthy propagating material, biological control, monitoring, and use of disease prediction models is recommended (Aćimović et al., 2015). The model indicated many regions that are suitable for E. amylovora and that have $M$. domestica plantations, though the pathogen has not yet been found. One such area is southern Brazil, where E. amylovora is not subject to a quarantine status according to Normative Instruction No. $39 / 2018$ of Brazil's Ministry of Agriculture, Livestock and Supply (MAPA, 2018). Because it is a highly aggressive, rapidly-spreading disease, and since there are currently no effective chemical treatments to control it, rapid diagnostic tests for early detection in areas that are free of the disease allow the destruction of infested material, which is essential for the control and eradication of the species (DGADR, 2011; Powney et al., 2011). Accordingly, it is important to carry out more detailed studies on the entry risk of this bacterium in Brazil, mainly because the southern region, where the production areas of $M$. domestica are concentrated, were demonstrated to be suitable for E. amylovora.

In contrast, the countries belonging to Mercosur that have shown suitability for E. amylovora in some regions, such as Argentina, Chile, Uruguay, Bolivia, Ecuador, Peru, and Colombia, have restrictions on the entry of fruits that are hosts to E. amylovora, as described in Mercosur Resolution No. 50/05 GMC (Mercosul, 2019). We observed in this study that all countries in South America that have suitability for the pest also have phytosanitary restrictions to prevent its entry, mainly through commercial relations with countries currently infested by E. amylovora. This work considered temperature and precipitation to determine suitability for $E$. amylovora and $M$. domestica. Thus, further studies considering other variables are necessary, such as the presence of other host species (pear and quince), the presence of natural enemies and antagonistic microorganisms, and the resistance of cultivars, among others.

Suitability maps are important tools for pest risk analyses, quarantine strategies, and to support phytosanitary actions. These results can help to develop strategies to prevent the introduction, dispersion, and establishment of E. amylovora, in addition to supporting future research and supporting biosafety practices.

This study presents relevant information about the potential risk of the worldwide distribution of E. amylovora in apple crops and the suitability of both species using the MaxEnt model. The maps can serve to support monitoring programs in countries where the species already occurs and to determine guidelines and measures to prevent the risk of invasion of E. amylovora in other regions.

\section{References}

Aćimović, S. G., Zeng, Q., Mcghee, G. C., Sundin, G. W., \& Wise, J. C. (2015). Control of fire blight (Erwinia amylovora) on apple trees with trunk- injected plant resistance inducers and antibiotics and assessment of induction of pathogenesis-related protein genes. Frontiers in Plant Science, 6, 16. https://doi.org/10.3389/ fpls.2015.00016

Boria, R. A., Olson, L. E., Goodman, S. M., \& Anderson, R. P. (2014). Spatial filtering to reduce sampling bias can improve the performance of ecological niche models. Ecological Modelling, 275, 73-7. https://doi.org/ 10.1016/j.ecolmodel.2013.12.012

Brown, J. L. (2014). SDM toolbox: A python-based GIS toolkit for landscape genetic, biogeographic and species distribution model analyses. Methods in Ecology and Evolution, 5, 694-700. https://doi.org/10.1111/ 2041-210X.12200

CABI (Centre for Agriculture and Biosciences International). (2019). Erwinia amylovora (fireblight). Invasive Species Compendium. 
Cambra, M., Palacio-Bielsa, A., Lozano, C., \& Crespo, J. (2002). El fuego bacteriano de las Rosáceas. Erwinia amylovora (Informaciones Técnicas 1).

Da Silva Galdino T. V., Kumar, S., Oliveira, L. S., Alfenas, A. C., Neven, L. G., ... Picanço, M. C. (2016). Mapping global potential risk of mango sudden decline disease caused by Ceratocystis fimbriata. PloS ONE, 11(7), e0159450. https://doi.org/10.1371/journal.pone.0159450

DGADR (Direcção-Geral de Agricultura e Desenvolvimento Rural). (2011). Manual de boas práticas para o controlo de fogo bacteriano (Erwinia amylovora) (Versão 1). Lisboa.

Elith, J., \& Leathwick, J. R. (2009). Species distribution models: Ecological explanation and prediction across space and time. Annual Review of Ecology, Evolution, and Systematics, 40, 677-97. https://doi.org/10.1146/ annurev.ecolsys.110308.120159

EPPO (European and Mediterranean Plant Protection Organization). (2004). Eppo Global Database, Erwinia amylovora. European and Mediterranean Plant Protection Organisation. Retrieved January 19, 2019, from https://gd.eppo.int/taxon/ERWIAM

EPPO (European and Mediterranean Plant Protection Organization). (2019). Eppo Global Database, Erwinia amylovora. European and Mediterranean Plant Protection Organisation. Retrieved January 19, 2019, from https://gd.eppo.int/taxon/ERWIAM/distribution

FAO (Food and Agriculture Organization of the Nations). (2016). Malus domestica. Food and Agriculture Organization of the United Nations. Retrieved January 19, 2019, from http://www.fao.org/faolex/ results/details/en/c/LEX-FAOC040474

Fatmi. (2011). Fire blight (Erwinia amylovora) the Moroccan experience. Proceedings of the Seminário Fogo Bacteriano: Uma abordagem mundial. Óbidos.

GBIF (Global Biodiversity Information Facility). (2019). Erwinia amylovora (Burrill, 1882). GBIF Backbone Taxonomy. https://doi.org/10.15468/39omei

Hijmans, R. J., Phillips, S., Leathwick, J., \& Elith, J. (2017). Species distribution modelling with R. R CRAN Project 2017. Retrieved March 20, 2019, from https://Cran.r-project.org/web/packages/dismo/vignettes/ sdm.pdf

Hijmans, R., \& Elith, J. (2013). Species distribution modeling with R. R Cran Project. Retrieved from http://cran.r-project.org/package=lme4

Hoffmann, A., \& Nachtigall, G. R. (2004). Fatores edafoclimáticos (pp. 25-31). Maçã: Produção; Bento Gonçalves: Embrapa Uva e Vinho; Brasília: Embrapa Informação Tecnológica.

Holt, J. (1994). Bergey’s Manual of Determinative Bacteriology (9th ed.). Williams and Wilkins, Baltimore.

Jarnevich, C. S., Stohlgren, T. J., Kumar, S., Morisette, J. T., \& Holcombe, T. R. (2015). Caveats for correlative species distribution modeling. Ecological Informatics, 29, 6-15. https://doi.org/10.1016/j.ecoinf. 2015.06.007

Johnson, K. B. (2000). Fire blight of apple and pear. The Plant Health Instructor, 2015. https://doi.org/10.1094/ PHI-I-2000-0726-01

Kriticos, D., Maywald, G., Yonow, T., Zurcher, E., Herrmann, N., \& Sutherst, R. (2015). CLIMEX Version 4: Exploring the effects of climate on plants, animals and diseases (p. 184). Canberra: CSIRO.

Kumar, S., Neven, L. G., \& Yee, W. L. (2014). Evaluating correlative and mechanistic niche models for assessing the risk of pest establishment. Ecosphere, 5, 1-23. https://doi.org/10.1890/ES14-00050.1

Kumar, S., Neven, L. G., Zhu, H., \& Zhang, R. (2015). Assessing the global risk of establishment of Cydia pomonella (Lepidoptera: Tortricidae) using CLIMEX and MaxEnt niche models. Journal of Economic Entomology, 108, 1708-19. https://doi.org/10.1093/jee/tov166

Liu, C., White, M., \& Newell, G. (2013). Selecting thresholds for the prediction of species occurrence with presence-only data. Journal of Biogeography, 40, 778-89. https://doi.org/10.1111/jbi.12058

Manel, S., Williams, H. C., \& Ormerod, S. J. (2001). Evaluating presence-absence models in ecology: the need to account for prevalence. Journal of Applied Ecology, 38, 921-31. https://doi.org/10.1046/j.1365-2664. 2001.00647.x

MAPA (Ministério da Agricultura, Pecuária e Abastecimento). (2018). Instrução Normativa no 39/2018. MAPA, Brasília. 
Mercosul (Mercado Comum do Sul). (2019). Tratamentos quarentenários Mercosul/GMC/RES. $N^{\circ}$ 50/05. Mercado Comum do Sul. Retrieved May 13, 2019, from https://www.mercosur.int/documentos-ynormativa/normativa

Merow, C., Smith, M. J., \& Silander Jr., J. A. (2013). A practical guide to MaxEnt for modeling species' distributions: what it does, and why inputs and settings matter. Ecography, 36, 1058-69. https://doi.org/10.1111/j.1600-0587.2013.07872.x

Norelli, J. L., Jones, A. L., \& Aldwinckle, H. S. (2003). Fire blight management in the twenty-first century: using new technologies that enhance host resistance in apple. Plant Disease, 87, 756-65. https://doi.org/10.1094/PDIS.2003.87.7.756

Owens, H. L., Campbell, L. P., Dornak, L. L., Saupe, E. E., Barve, N., Soberón, J., ... Peterson, A. T. (2013). Constraints on interpretation of ecological niche models by limited environmental ranges on calibration areas. Ecological Modelling, 263, 10-8. https://doi.org/10.1016/j.ecolmodel.2013.04.011

Palacio Bielsa, A., \& Cambra Alvarez, M. A. (2009). El Fuego Bacteriano de las rosáceas (Erwinia amylovora) (p. 95). Ministerio de Medio Ambiente y Medio Rural y Marino.

Paulin, J.-P. (2000). Erwinia amylovora: general characteristics, biochemistry and serology. Fire blight: The disease and its causative agent, Erwinia amylovora (pp. 87-117). https://doi.org/10.1079/978085 1992945.0087

Peterson, A. T., \& Soberón, J. (2012). Species distribution modeling and ecological niche modeling: getting the concepts right. Natureza \& Conservação, 10, 102-7. https://doi.org/10.4322/natcon.2012.019

Phillips, S. J., \& Dudík, M. (2008). Modeling of species distributions with Maxent: new extensions and a comprehensive evaluation. Ecography, 31, 161-75. https://doi.org/10.1111/j.0906-7590.2008.5203.x

Phillips, S. J., Anderson, R. P., \& Schapire, R. E. (2006). Maximum entropy modeling of species geographic distributions. Ecological Modelling, 190, 231-59. https://doi.org/10.1016/j.ecolmodel.2005.03.026

Powney, R., Smits, T. H., Sawbridge, T., Frey, B., Blom, J., Frey, J. E., ... Rodoni, B. (2011). Genome sequence of an Erwinia amylovora strain with pathogenicity restricted to Rubus plants. Journal of Bacteriology, 193, 785-6. https://doi.org/10.1128/JB.01352-10

Raymundo, A. K., \& Ries, S. M. (1980). Chemotaxis of Erwinia amylovora. Phytopathology, 70, 1066-9. https://doi.org/10.1094/Phyto-70-1066

Ripley, B. D. (2001). The R project in statistical computing. MSOR Connections. The Newsletter of the LTSN Maths, Stats \& OR Network, 1, 23-25. https://doi.org/10.11120/msor.2001.01010023

Rodoni, B., Kinsella, M., Gardner, R., Merriman, P., Gillings, M., \& Geider, K. (1998). Detection of Erwinia amylovora, the causal agent of fire blight, in the Royal Botanic Gardens, Melbourne, Australia. Proceedings of the VIII International Workshop on Fire Blight, 489, 169-70. https://doi.org/10.17660/ActaHortic. 1999.489 .25

Team R. C. (2014). R: A language and environment for statistical computing. R Foundation for Statistical Computing, Vienna, Austria.

Thomson, S. (2000). Epidemiology of fire blight. In J. L. Vanneste (Ed.), Fire Blight, The Disease and its Causative Agent, Erwinia amylovora. CABI Publishing, Wallingford, NY.

USDA (United States Department of Agriculture). (2019). Erwinia amylovora. U.S. Department of Agriculture.

Vilela, E. F., \& Callegaro, G. M. (2013). Elementos de defesa agropecuária: Sistema normativo, invasões biológicas, comunicação, história, risco e segurança dos alimentos, conformidade e rastreabilidade. Piracicaba: FEALQ.

Winslow, C., Broadhurst, J., Buchanan, R. E., Krumwiede, C., Rogers, L. A., \& Smith, G. H. (1920). The families and genera of the bacteria: final report of committee of the Society of American Bacteriologists on characterization and classification of bacterial types. Journal of Bacteriology, 5(3), 191. https://doi.org/ 10.1128/JB.5.3.191-229.1920 


\section{Copyrights}

Copyright for this article is retained by the author(s), with first publication rights granted to the journal.

This is an open-access article distributed under the terms and conditions of the Creative Commons Attribution license (http://creativecommons.org/licenses/by/4.0/). 